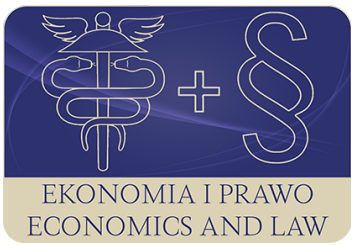

EKONOMIA I PRAWO. ECONOMICS AND LAW

Volume 15, Issue 4, December 2016

p-ISSN 1898-2255, e-ISSN 2392-1625

www.economicsandlaw.pl

EKONOMIA I PRAWO
ECONOMICS AND LAW

ORIGINAL ARTICLE

received 09.06.2016; revised 07.10.2016; accepted 31.12.2016

Citation: Ryczkowski, M. (2016). Modern central banking from monetary perspective. Ekonomia

iPrawo. Ecomomics and Law, 15(4): 547-556. doi:10.12775/EiP.2016.037.

\title{
Modern central banking from monetary perspective
}

\author{
MACIEJ RYCZKOWSKI
}

Nicolaus Copernicus University, Faculty of Economic Sciences and Management, Department of Economics, ul. Gagarina 13A, 87-100 Toruń, Poland

曰m_ryczkowski@umk.pl

\begin{abstract}
Motivation: Cashless or DSGE models did not allow to predict the Great Recession which may suggest that they omit some important variables like money or credit, for instance.

Aim: The paper summarizes changing views on money's importance in modern monetary policy and reviews pros and cons of assigning any special role to money by central banks. Results: On the basis of literature review and the 2007-2009 crisis experiences, author apposes arguments for possible improvements in monetary policy frameworks. The paper is organized as follows: section 1 reviews some basic facts about monetary aggregates, section 2 presents the methodology of the research, section 3 discusses pros and cons of assigning special relevance to money in central banking, section 4 concludes.
\end{abstract}

Keywords: money; monetary aggregates; modern central banking

JEL: E42; E51; E52; E58

\section{Introduction}

Although the role of money in modern central banking has been depreciated (Meyer, 2001, pp. 1-15), there is no common agreement about the justification of potential, flexible, long-term monetary targeting or assigning some special importance to money, like it is in case of the European Central Bank (ECB) (Wojtyna, 2008, pp. 1-20). This issue is especially important during quantitative easing $(\mathrm{QE})$ as there are no definite validation measures allowing to estimate whether monetary stimulus is not overly excessive from the long-term optimal point of view. There are no indicators monitoring the right pace and timing 
of exit strategies. As a result, that may bring negative consequences in the long run.

The paper elaborates on the issues of money in modern central banking. On the basis of literature review and recent 2007-2009 crisis experiences, author discusses arguments for possible improvements in monetary policy frameworks. Both deductive and inductive logic is applied to verify the need for any institutional changes. The paper maps out the scope of possible further research concerning the role of money.

\section{The current state of knowledge on money role}

The basic facts about money are: money became highly endogenous; the relation described by LM curve largely broke; demand for money has increased considerably in all countries; control for money stock is either impossible or very difficult, rising imbalances between economic growth and money stock generally did not lead to missing the inflation target as central banks take into account money velocity changes; low consumer inflation does not protect from asset market bubbles (BIS, 2007, pp. 70-78); which might cause financial instability; which in terms of zero lower bound on nominal interest rates may be solved by nonconventional monetary policy.

The evidences of money endogeneity are clear and strong (Niggle, 1990, pp. 443-450). Even the founder of monetarism, Milton Friedman (2004, pp. 349 351 ), admitted that money started to be largely endogenous and that he would not insist on monetary targeting as he once did (London, 2003, pp. 12-13). The view of money endogeneity is widespread among academia and practitioners from central banks since long time ago (Goodhart, 1994, pp. 1424-1436). Money endogeneity makes monetary targeting problematic and alternatively possible for a very long run and with high dose of elasticity.

Undoubtedly, increasing demand for money caused distortions in the relation between money stock, economic growth and prices. The effects of endogenous money and decreasing money velocity are reflected in irregular shape of LM curve. Orthodox macroeconomic model IS-LM assumes that money stock is determined exogenously by central banks, which is nowadays not true. Most central banks pay little attention to monetary aggregates in conducting monetary policy. This flaw of IS-LM model, among many others offered in literature, is so serious, that in words of Romer (2000, pp. 149-170) 'is likely to be fatal' for a standard version of this model. The perished and gone once and for all constant money multiplier cause that the slope of LM curve can plausibly take any sign (Black \& Dowd, 1994, pp. 301-310).

Contrary to quantity theory of money's predictions, growing disparity between economic growth and money stock did not lead to inflation pressures in terms of consumer price index (CPI). The reason for this is that central banks take into account changes in money velocity. Such results confirm the current state of knowledge: that prominent, modern central banks are effective at CPI 
inflation control despite depreciation of the money role in their considerations. Perhaps only while hyperinflation, during strongly unanchored inflation expectations, central bank's standard instruments would be not sufficient to disinflate. No such situation happened yet under any inflation targeting regime and is unlikely to ever happen, as theoretically there exists no upper bound for interest rate instrument.

This is the argumentation that Woodford (2008, pp. 1561-1598) probably had in mind stating that: 'one does not need to monitor money growth to tell if an undesirable long-run inflation trend is developing; measurement of inflation itself suffices for this'. Unfortunately, contrary to what we could have hoped for, price stability does not guarantee financial stability. We have learned from the 2007-2009 crisis that those who had warned us that in some circumstances low inflation accompanied by macroeconomic stability might increase the risk of a serious financial instability, were right. Risk-taking behavior, low CPI inflation and famous 'irrational exuberance' may transform investments into bubbles. When bubbles burst, they create crises and threaten the financial and price stability. The 2007-2009 crisis proved that financial frictions may be a much more serious problem than it had been anticipated. Decline of money supply caused by aversion to lending escalated by a fall of aggregated demand may have a strong, negative impact on business cycle fluctuations. Therefore, although it was recognized earlier that financial disturbances may be harmful for the economy, the crisis demonstrated that their effects may be potentially extremely severe and thus financial frictions ought to be an important variable in macroeconomic analyses.

When bubble bursts money demand quickly declines due to credit crunch. Money stock drives down too. When this happens and when market players do not trust each other to let the money be borrowed at reasonable cost, then there is a necessity to implement expansionary policy including lender of the last resort function - what was already recognized by monetarists over 50 years ago after the Great Depression.

Nonetheless the crisis 2007-2009 confirmed that lowering official interest rates may be like the predicted 'pushing on a string' or 'bringing a horse to a water'. Interest rate instrument does not guarantee lower interest rates on the money market or increased lending. When credit crunches, banks do not want to borrow from each other and money stock declines. Although prominent central banks do not target monetary aggregates, in order to follow expansionary policy in terms of a zero bound, they must ask forgiveness to money stock. To balance falling money stock, in order to avoid short term significant output reduction, central banks need to take nonconventional steps to encourage lending and, in fact, to increase the growth of money stock.

In order to support conventional monetary policy near zero bound, especially during financial frictions that threaten stability of the economy, additional monetary impulse might be created either through negative interest rates or through wide range of quantitative easing measures. 
Negative interest rates turned out quite recently to be not only a theoretical possibility but more and more 'charted waters'. Negative rate for 7-day deposits at $-0.25 \%$ was set for the first time by Sveriges Riksbank (2016) in July 2009 and in September 2010. Next was the Denmark's Nationalbank (2016), which in July 2012 set its 14 -day deposit rate at $-0.2 \%$, which was the consequence of a fixed exchange rate policy. Afterwards an important experiment took place in the euro zone. Since June 2014 the deposit facility of ECB (2016) is negative and equals $-0.10 \%$.

Negative deposit rate rest on the assumption that currency is not costless to hold. Therefore, commercial banks have only two choices: either to lend money to other banks or to pay the negative deposit rate. Negative deposit rate may therefore support lending and act inflationary during financial frictions. However, there are good reasons to claim that negative rates (even in its forward looking version) are not a sufficient tool to solve the liquidity problem. First, there exists a logical floor for rates. When costs of paying the negative interest rates exceed storage costs, banks may become interested in money storage. Second argument is the 'pushing the string' inefficiency problem. Banks will not lend to each other if market agents do not trust each other so much that risk premia exceed costs of paying the negative rates. Finally, it would be problematic to lower rates other than the deposit ones. Otherwise, it would be profitable for commercial banks to take infinitely big credits from central banks. This would possibly have sense under the condition of some kind of limits for those credits. All in all, it seems that negative interest rates cannot be considerably negative anyway.

Therefore, to support conventional monetary policy and insufficient interest rates decisions in terms of liquidity problem, nonconventional monetary policy may be necessary. Already M. Friedman and A.J. Schwartz (1971) in famous book while explaining the role of money claimed that an increase of money stock and a helping hand to the Bank of United States during the Great Depression were the remedies that unfortunately were not applied. Nowadays, such a passive role of central banks in times of financial frictions is unaccepted both from monetarist and keynesian point of view. Banks implemented the nonconventional tools in order not to allow for the destabilization of the real economy. Nonconventional monetary policy includes broad group of actions abbreviated $\mathrm{QE}$ which stands for quantitative easing and qualitative easing. The aim of QE is to provide commercial banks with excess liquidity to promote private lending and to affect the market by other means than interest rate channel.

Generally nonconventional monetary policy might take three basic forms: 1) liquidity provisions in which central banks expand lending to both banks and other financial institutions, 2) asset purchases of both government securities and private assets in order to lower the borrowing costs for households, 3) management of expectations in which central banks commit to keep their policy rate at very low levels for a long period of time (Mishkin, 2011, pp. 1-63). 
Among rife set of indirect qualitative easing can be listed: the provision to banks of unlimited liquidity at a fixed rate in all refinancing operations against adequate collateral; the lengthening of the maximum maturity of refinancing operations; the extension of the list of assets accepted as collateral; the provision of liquidity in foreign currencies; swap facilities for foreign currencies and outright purchases in the covered bond market (ECB, 2010).

Recent crisis 2007-2009 demonstrated that supervision at micro level accompanied by stable prices and stable macroeconomic environment do not ensure, at best, financial stability (Rosati, 2014, pp. 373-406.). In these circumstances an important role ought to be assigned to macro prudential analyses.

\section{The methodology of research}

The main method used in the article is a descriptive-analytical one. Based on literature review on advantages and disadvantages of assigning to money a key importance in setting the central bank's instruments, in the article are drawn conclusions about the presumably preferable money's role in modern monetary policy. The conclusions base on inductive and deductive logic. In the article are also indicated fields that require research in the future.

\section{Pros and cons of money monitoring}

There is a whole bunch of good arguments, which indicate that indeed money does not deserve to have special attention in monetary policy:

- Money stock itself is considered to be of little importance as in fact it cannot be controlled and changes along with variable money demand.

- Modern central banks are effective at inflation control and output gap reduction even in transition countries characterized by strong inflation pressures and awkward initial conditions. Although inflation targeting might not guarantee a 'free lunch' during disinflation (Mishkin, 2001, pp. 1-42) and even though disinflation and output variability mitigation in recent decades were reinforced by global trends (Ball \& Sheridan, 2003, pp. 1-50; White, 2006; pp. 1-22; Lee, 1999, pp. 332-347), the fair performance of prominent central banks is generally not questioned and it led some authors to conclude that flexible inflation targeting enriched by 'central bank judgment' may be in fact the optimal monetary policy (Svensson, 2006, pp. 1-45; Woodford, 2007, pp. 3-24).

- No need to control money aggregates in order to achieve low and stable inflation might be derived from cashless models ('new Keynesian', 'neo-Wicksellian' models). It turns out that the mathematical equilibrium of the model presented by Woodford (2008, pp. 1561-1598) is the inflation rate, which fluctuates around a stochastic trend given by the central bank's inflation target. According to such models, control of monetary aggregates is not required to meet the inflation target criterion. 
- Some warn that additional monetary control may contest transparency of such policy (Begg et al., 1999), especially that money stock turned out to be an unreliable predictor alerting about potential speculative price booms. Almost 2/3ds cases of excessive liquidity growths have not created asset price bubbles (Posen, 2006, pp. 109-124).

The reasoning mentioned above has, however, caveats. First, even the opponents of monetary control usually agree that monetary aggregates might deliver additional information for monetary policy decisions. Hence, King (2003, pp. 62-90) warns that ignoring money growth might be a mistake, as models which omit money might not sufficiently represent the complexity of the world. Cashless models poorly explain the importance of money in monetary transmission mechanism. Goodfriend and McCallum (2007, pp. 1480-1507) indicate that cashless models and money role depreciation might in certain circumstances cause serious mistakes in setting the proper central bank interest rates. In opinion of Goodhart (2007, pp. 56-61), default, risk aversion, income constraints matter and ought to be compared with the messages emanating from the monetary aggregates. Goodhart emphasizes the difficulties with setting the interest rate in times of economic destabilization. Therefore, some economists believe that control whether monetary growth path is compatible with current paths of production, inflation and interest rates ought to be carried out.

The opinions in favor of special money role in endogenous money environment manifest themselves through establishment of the two-pillar approach by the ECB $(2004$, p. 55). The justification for creation of a separate monetary pillar rests upon evidences of long-term connection between money and prices. Those opinions often rest upon long-run empirical relationship between money growth and inflation across variety of countries, periods of time and different monetary regimes. Excessive money supply in opinion of some economists may therefore eventually lead to inflationary pressures (King, 2003, pp. 62-90; Haug \& Dewald, 2004, pp. 1-39). Recent empirical evidences show, however, that quantity theory of money may have lost its explanatory power (Teles et al., 2016, pp. 442-464). Nevertheless, taking into account the large burden of evidences in favor of the monetarist theory, more empirical research seems to be required at low frequencies.

In opinion of Woodford (2007, pp. 3-24), for instance, we should not be afraid of possible, future inflation as interest rate instrument suffices to disinflate. As he correctly ascertains, monetary growth does not need to be monitored to notice rising inflation. Therefore, the inflation target will not be in danger even when the monetary growth would be large enough to cause inflation pressure. Such 'wait and see' strategy may be contested. The problem of excessive monetary growth's possible, long-term threats should not be formulated only in terms of meeting the inflation target. The crucial question in the long run would be also whether after previously experienced excessive monetary growths the probability of financial instability is going to increase in the long run, whether it will cause moral hazard or asset price bubbles? 
Meanwhile asset prices are not controlled by central banks and are not subject to international competition. In turn, asset bubbles threat financial stability and affect negatively long run potential output, while leaving huge number of resources wasted. Already some researchers have gone that way and indeed results imply that evident relation between monetary aggregates and more general price indices does exists (Andersson, 2011, pp.759-770; Issing, 2009, pp. 45-51). Such results may cause money once again to play an important role in monetary policy (see an example of such role in Gerdesmeier et al., 2010, pp. 377-407). The unresolved area in monetary policy is, therefore, how central banks should respond to asset price bubbles.

Additionally, ultra easy monetary policy might bring unintended medium-term consequences. To that undesirable medium term effects might be included malinvestments in the real economy, deterioration of financial institutions' health and deterioration of financial markets' functioning, constraint of the central banks' independence in pursuing price stability, encouragement for governments to refrain from confronting sovereign debt problems in a timely way, and problems with redistribution of income and wealth between debtors and creditors (White, 2013, pp. 19-56). Other possible harmful effects of extremely easy monetary policy which is not subject to some reasonable constraints, may include moral hazard and adverse selection problems at the credit market.

However, when interest rates are close or even below zero floor and while $\mathrm{QE}$ is on, it is unknown what should be the proper exit strategy from quantitative easing. That in fact forms a question: 'when and how fast' EQ should be stopped. Therefore, 'exit' from such a policy is difficult. There are no common frameworks or procedures which would be able to formally stop the monetary expansion. It led Taylor (2009, pp. 63-72) to propose a comeback to some kind of a monetary rule of Friedman type for monetary base. Nonetheless, such solution would not probably have strong impact on the stability of broader monetary aggregates as money multiplier is not constant anymore.

It might be assumed that for every given period in the economy exists optimal magnitude of money stock. Since broad money aggregates cannot be perfectly controlled even in the long run due to money endogeneity and since optimal supply of money changes along with changing external conditions (like expectations) we may expect that there exists 'lower' and 'upper limit' of money stock, which should not be crossed. The lower limit is simple to define. It is so small money stock that payment backlogs start to appear. For every economy in specific period exists 'upper limit' too. Nonetheless, central banks do not know what is the value of the upper limit. Therefore, while using QE we can never be sure, whether we already crossed the upper limit.

Taking the possible consequences into account, it seems reasonable that easy monetary policy should be pursued only to bring back financial stability. Unfortunately we cannot be sure whether 'breaks' will be always pushed in the right moment and with appropriate strength. After all, since long time ago it is well 
known that monetary policy cannot boost economic growth in the long run. There are no 'free lunches' while QE. Monetary policy cannot be treated as a tool to foster economic growth in the absence of structural reforms and wise investments, especially that negative demographic tendencies might increase the budget deficits in many countries (due to retirement pensions), which in terms of monetizing the debt may contribute to fiscal dominance (Marszatek, 2007, pp. 99-220). Therefore, the question arises whether central bank awareness of this danger is enough or some flexible monetary frameworks are required to prevent crossing the 'upper limit' of monetary growth or credit expansion. If the answer would be 'yes', then more empirical research is needed to ascertain how should monetary management be introduced into modern central banks' models. Already the empirical literature on adjusting the consensus macro models with money and financial frictions is still growing (Brzoza-Brzezina et al., 2013, pp. 32-51). Otherwise, discretion in the field of implementing easy monetary policy in times of financial frictions would depend strongly on the abilities of particular central bankers.

\section{Conclusion}

In the long run unhampered quantitative easing programmes may potentially cause financial instability not only through CPI inflation channel, but also through rising asset, real estate or stock prices, asset bubbles, depreciation of the exchange rate, growing imbalances, malinvestments, moral hazard, adverse selection problems, decreased incentives for structural reforms while presence of 'easy money', fiscal dominance which altogether might lead to a deterioration of optimal use of limited resources and eventually to welfare losses, economic slowdown or to a crisis. Additionally in the article it was found that more research is required not only on the quantity theory of money at very low frequencies in modern, deregulated financial systems and in countries with low consumer inflation, but also on how to respond to asset price bubbles, how to implement money and financial frictions into macro models, what are the long run cost and benefits of flexible monetary targeting like in the case of the ECB and what institutional changes should be carried out in terms of monetary policy to contribute not only to low and stable consumer inflation but also to financial stability.

The costs of high consumer inflation indicate that the basic goal of the central banks shall remain to maintain price stability in the medium term. Additionally, the experiences with the recent crisis seem to suggest that central banks shall aim to guard the financial stability not only by micro but also by macroprudential policies. Monetary aggregates may be one of the variables required for the detailed macro analysis. 


\section{References}

Andersson, F.N. (2011). Monetary Policy, Asset Price Inflation and Consumer Price Inflation. Economics Bulletin, 31(1).

Ball, L., \& Sheridan, N. (2003). Does Inflation Targeting Matter? NBER Working Paper, 9577. doi:10.3386/w9577.

Begg, D., Wyplosz C., De Grauwe, P., Giavazzi, F., \& Uhling, H. (1999). Monitoring the European Central Bank update: May 1999. London: CEPR.

BIS. (2007). 77th Annual Report. Retrieved 30.12.2016 from http://www.bis. org.

Black, D.C., \& Dowd, M.R. (1994). The money multiplier, the money market, and the LM curve. Eastern Economic Journal, 20(3).

Brzoza-Brzezina, M., Kolasa, M., \& Makarski, K. (2013). The anatomy of standard DSGE models with financial frictions. Journal of Economic Dynamics and Control, 37(1). doi:10.1016/j.jedc.2012.06.008.

Danmarks Nationalbank. (2016). Retrieved 10.12.2016 from https://www.nationalbanken.dk.

EBC. (2016). Retrieved 30.12.2016 from https://www.ecb.europa.eu.

ECB. (2004). The Monetary Policy of the ECB 2004. Retrieved 30.12.2016 from https://www.ecb.europa.eu.

ECB. (2010). The ECB's Monetary Policy Stance During the Financial Crisis. Retrieved 30.12.2016 from https://www.ecb.europa.eu.

Friedman, M. (2004). Reflections on a Monetary History. Cato Journal, 23(3).

Friedman, M., \& Schwartz, A.J. (1971). AMonetary History of the UnitedStates18671960. Princeton: Princeton University Press. doi:10.1515/9781400829330.

Gerdesmeier, D., Reimers, H.E., \& Roffia, B. (2010). Asset Price Misalignments and the Role of Money and Credit. International Finance, 13(3). doi:10.1111/j.1468-2362.2010.01272.x.

Goodfriend, M., \& McCallum, B.T. (2007). Banking and interest rates in monetary policy analysis: A quantitative exploration. Journal of Monetary Economics, 54(5). doi:10.1016/j.jmoneco.2007.06.009.

Goodhart, C.A. E. (2007). Whatever became of the monetary aggregates? National Institute Economic Review, 200(1). doi:10.1177/0027950107080389.

Goodhart, C.A.E. (1994). What Should Central Banks Do? What Should Be Their Macroeconomic Objectives and Operations? The Economic Journal, 104(427). doi:10.2307/2235461.

Haug, A.A., \& Dewald W.G. (2004). Longer-Term Effects of Monetary Growth on Real and Nominal Variables, Major Industrial Countries, 18802001. ECB Working Paper, 382.

Issing, O. (2009). Asset Prices and Monetary Policy. Cato Journal, 29(1).

King, M.A. (2003). No Money, No Inflation - The Role of Money in the Economy. In P. Mizen (Ed.), Central Banking, Monetary Theory and Practice. Essays in Honour of Charles Goodhart. Cheltenham-Northampton: Edward Elgar. do i:10.4337/9781781950777.00023. 
Lee, J. (1999). Inflation Targeting In Practice: Further Evidence. Contemporary Economic Policy, 17(3). doi:10.1111/j.1465-7287.1999.tb00686.x.

London, S. (2003). Lunch with the FT - Milton Friedman: The Long View. Financial Times Magazine supplement, 7.

Marszałek, P. (2007). Podstawy fiskalnej teorii poziomu cen, Ekonomista, 2.

Meyer, L.H. (2001). Does Money Matter? Federal Reserve Bank of St. Louis Review, September/October.

Mishkin, F.S. (2001). From Monetary Targeting to Inflation Targeting: Lessons from the Industrialized Countries. Policy Research Working Papers, 2684. doi:10.1596/1813-9450-2684.

Mishkin, F.S. (2011). Monetary policy strategy: lessons from the crisis. NBER Working Paper, 16755.

Niggle, C.J. (1990). The Evolution of Money, Financial Institutions, and Monetary Economics. Journal of Economic Issues, 24(2), doi:10.1080/00213624.1 990.11505043.

Posen, A.S. (2006). Why Central Banks Should Not Burst Bubbles. International Finance, 9(1). doi:10.1111/j.1468-2362.2006.00028.x.

Romer, D. (2000). Keynesian Macroeconomics without the LM Curve. Journal of Economic Perspectives, 14(2). doi:10.1257/jep.14.2.149.

Rosati, D.K. (2014). Regulacje makroostrożnościowe a stabilność sektora bankowego. Bank i Kredyt, 45(4).

Svensson, L.E.O. (2006). Optimal Inflation Targeting: Further Developments of Inflation Targeting. Central Bank of Chile Working Papers, 403.

Sveriges Riksbank. (2016). Retrieved 30.12.2016 from http://www.riksbank. se.

Taylor, J.B. (2009). The Need to Return to a Monetary Framework. Business Economics, 44(2). doi:10.1057/be.2009.1.

Teles, P., Uhlig, H., \& Valle e Azevedo, J. (2016). Is Quantity Theory Still Alive? The Economic Journal, 126(591). doi:10.1111/ecoj.12336.

White, W.R. (2006). Is price stability enough? BIS Working Papers, 205. doi:10.2139/ssrn. 900074 .

White, W.R. (2013). Ultra Easy Monetary Policy and the Law of Unintended Consequences. Real-world Economics Review, 63.

Wojtyna, A. (2008). Polityka pieniężna w strefie euro: dawne obawy, nowe wyzwania. Gospodarka Narodowa, 11-12(207-208).

Woodford, M. (2007). The Case for Forecast Targeting as a Monetary Policy Strategy. Journal of Economic Perspectives, 21(4). doi:10.1257/jep.21.4.3.

Woodford, M. (2008). How Important Is Money in the Conduct of Monetary Policy? Journal of Money, Credit and Banking, 40(8). doi:10.1111/j.1538-4616.2008.00175.x.

\section{Acknowledgements}

Author contributions: author have given approval to the final version of the article. 